\title{
A Study on the Semi Strong Form of Efficiency in Indian Stock Market
}

\author{
Effulgence \\ Vol. 16 No. 1 \\ January - June, 2018 \\ Rukmini Devi Institute of Advanced Studies \\ E-mail : effulgence@rdias.ac.in, Website : www.rdias.ac.in \\ http:/ / effulgence.rdias.ac.in/user/default.aspx \\ https://dx.doi.org/10.33601/effulgence.rdias/v16/i1/2018/94-107
}

\section{Dr. Pardeep Gupta ${ }^{1}$ \\ Supriya Sardana ${ }^{2}$}

\begin{abstract}
Purpose- The main purpose of this research study is to investigate semi strong form of efficient market hypothesis of the firms constituting Nifty 50 .

Design/Methodology- The Research Design is Descriptive. The variables in the study are daily closing prices of sample firms, NIFTY 50 index and the time period. Prior to the testing of semi strong form of efficiency, weak form of efficiency has been tested by using Serial Correlation (parametric) test (Reilly and Brown, 2012). Then, Event study methodology (Elton and Gruber, 2002) using daily returns and Ordinary Least Square (OLS) market model (Brown and Warner, 1985) have been used in the study to test the semi strong form of efficiency. The event taken in the study is demonetisation announcement made in 2016. Z test has been used to test the significance of the abnormal returns around the demonetisation announcement date (Das et.al. 2014). $t$ - test has been used to test the significant difference in the average abnormal returns before and after the demonetisation announcement date (Ramachandran, 2012; Lahiri, 2012).
\end{abstract}

Findings- The market is found to be efficient in its both weak and semi strong form i.e. no investor can earn the abnormal return based on the historical and current publicly available information.

Research limitations and Future Scope - The study has been undertaken using the firms constituting NIFTY 50. The study with reference to firms listed in other indices may provide different sets of results. For future research, share prices reaction to other microeconomic and macroeconomic events taking different sectors can be considered.

Contribution of the Paper - The research on EMH is important as it has significant real world implications for investors and portfolio managers. To protect the interest of the investors in the capital market, the efficiency of the market plays a vital role (Kummeta, 2015). The investors now pay more attention to all the events and patterns that influences the share price

1. Professor, Haryana School of Business, Guru Jambheshwar University of Science \& Technology, pardeephsb@gmail.com

2. Research Scholar, Haryana School of Business, Guru Jambheshwar University of Science \& Technology, sardanasupriya1994@gmail.com

Corresponding Author

Supriya Sardana, Haryana School of Business, Research Scholar, Guru Jambheshwar University of Science \& Technology, sardanasupriya1994@gmail.com 
movements in the stock market. The events influencing the security prices may be either controlled by the companies or may be forced by the external factors. Therefore, knowing the efficiency of Indian Stock Market is required.

Keywords: Event study, Demonetisation, Nifty 50, T test, Z test, Serial Correlation test, OLS Market model, Weak form, Semi strong form, Efficient Market Hypothesis.

\section{INTRODUCTION}

A market in which prices always "fully reflect" available information is called efficient (FAMA, 1970). The Efficient Market Hypothesis (EMH) suggest that profiting from predicting price movements is very difficult and unlikely (Clarke et.al). Fama divided EMH into three sub hypotheses depending upon information involved: (1) weak form EMH i.e. all historical information is reflected in the current prices, (2) semi strong from EMH i.e. publicly available information is reflected in the current prices, (3) strong from EMH i.e. all information whether public or private is fully reflected in the stock prices (Reilly \& Brown, 2012). Fama presented the efficient market theory in terms of a "fair game model" which says that there is no way to use "information" available at a point of time (t) to earn a return above the normal. A more restricted version of fair game model is "Random Walk Model" which assumes that successive returns are independent and returns are independently distributed over time (Elton and Gruber, 2002). The literature on the evidence of EMH is mixed. Some have supported the hypotheses and others have revealed some anomalies indicating that do not support hypothesis. Researchers have formulated two groups of tests of weak form of EMH: (1) Statistical tests of independence that includes auto correlation and runs test (2) Tests of trading rules. Studies that have tested semi strong form EMH can be divided into two sets: (1) Studies to predict future rates of return using available public information beyond pure market information such as prices and trading volume as in weak form tests. (2) Event studies that examine how fast the stock prices adjust to economic events (Reilly \& Brown, 2012). This study aims to test the hypothesis of market efficiency of the Indian stock market in its weak form using runs test and semi strong form by studying the stock market reaction to the demonetisation announcement made in the year 2016 using the Event Study Methodology. The framework is based on the discussion of Event Study by Elton and Gruber, 2002.

\section{LITERATURE REVIEW}

Fama et. al (1969) examined the behaviour of the stock prices in the months around the split and found that information implication of stock split was fully reflected in the prices of shares indicating efficiency of the Market. Howe (1986) examined the over reaction of the US stock market to the favourable and unfavourable events leaving the opportunity to earn significant abnormal returns. Olowe (1998) revealed the inefficiency of the Nigerian Stock Market in its semi strong form as significant abnormal returns could be earned till two months after the stock split announcement month. Ahmed (2002) revealed the inefficiency of the Bangladesh's stock market in its weak form as the auto correlation coefficient is different from zero thus rejecting the random walk hypothesis. Huang (2004) revealed inefficiency of the China's stock market in its semi strong form as significant abnormal returns could be earned with the positive and negative financial announcements. Robinson (2005) revealed the inefficiency of the Jamaica stock market in its weak form as the daily returns data do not follow random walk. Ahmad et. al. (2006) revealed the inefficiency of Indian stock market in its weak form using Runs test, Unit root test and ACF test. Raja (2008) revealed inefficiency of the Indian stock market by examining the share price reactions on the announcements namely Merger and Acquisition, Stock Split, Buy back, Right Issue, 
Bonus Announcement. Stock Market positively received the information leaving the opportunity for earning abnormal returns. Patten (2008) revealed the opportunity of earning significant positive abnormal returns around the corporate philanthropy announcement in South Asian Countries as the stock market positively reacted to the information. Lahiri (2012) revealed that the market is neither efficient in its weak nor in semi strong form as the market do not follow random walk model and significant abnormal returns could be earned during the Stock Split and Corporate Earnings announcements thus rejecting EMH. Kumar e.t. al. (2012) found that the dividend announcement did not have any impact on the stock return behaviour indicating efficiency of the Indian Stock Market. Bapusaheb (2012) examined efficiency of Indian stock market in its weak form and obtained mixed results. Unit root tests supported the random walk hypothesis whereas Auto correlation and Runs test rejected the same. Ramachandran (2013) examined no change in the security prices and trading volume before and after the announcements namely dividend, bonus issue, stock split and Merger thereby supporting the EMH. Kummeta (2015) revealed the efficiency of the Indian stock market in its semi strong form by examining share price reaction to announcements namely Bonus share, Merger and Acquisition, Dividend, Right Issue. The information did not influence the market in significant manner. Gupta (2015) examined that the stock market seemed to adjust Union Budget information within a short period itself i.e. three days surrounding the budget announcement thus indicating the efficiency of the Indian stock market. Biktimirov and Durrani (2017) examined the share price reactions of Toronto Stock Exchange listed companies to the announcements of corporate name changes and found significant run up in the prices and the trading volume.

\section{RESEARCH METHODOLOGY}

\section{Objective of the Study}

The main objective of the study is to investigate semi strong form of Efficient Market Hypothesis of the firms constituting NIFTY 50 by studying stock market reaction to the demonetisation announcement made in the year 2016. The study also tests the weak form of market efficiency using actual returns earned on share prices of firms constituting NIFTY 50 applying the Runs test.

\section{Hypotheses of the Study}

H01: The Indian stock market is efficient in its weak form.

H02: The Indian stock market is efficient in its semi strong form i.e., no abnormal profit can be reaped by the investors in the Indian stock market on the basis of publicly available demonetisation information. To test this two hypothesis have been formulated H02aThe AARs of the sample firms is zero in the event window (Das et.al. 2014). H02b- There is no significant difference in the AARs before and after the announcement of demonetisation (Das et.al. 2014).

\section{Data and their Source}

The study is based on 50 firms in NSE constituting NIFTY 50. Variables used in the study are daily closing prices of the firms ranging from 1st January 1st December 2016 have been taken up for the study from website of NSE.

\section{Statistical Tools Used}

In order to test for weak-form efficiency, Serial (Auto) Correlation test has been used. The term serial correlation may be defined as "correlation between members of series of observations ordered in time series data or in cross sectional data. In regression context, linear regression model assumes that such auto correlation does not exist in the disturbances ei .

The Durbin Watson Test and Breusch Godfrey (LM) are used to test the significance of auto correlation in residuals (disturbances). The Hypothesis for the test 
are:

$\mathbf{H 0}=$ There is no auto correlation

H1 = The auto correlation exists in the series.

The test statistic is calculated with the following formula:

$$
D W=\frac{\sum_{t=2}^{T}\left(e_{t}-e_{t-1}\right)^{2}}{\sum_{t=1}^{T} e_{t}^{2}}
$$

Where, et are the residuals from the regression equation.

The Durbin Watson test reports a test statistic, with a value from 0 to 4 , where:

- 2 is no autocorrelation.

- 0 to $<1$ is positive autocorrelation

- $>3$ to 4 is negative autocorrelation

- 1 to 3 is zone of indecision

But Durbin Watson test can is used to detect first order correlation and it has a zone of indecision, therefore along with this we will use Breusch Godfrey (LM) test which helps in identification of higher order correlation as in LM test lagged values of the regressand can be added to the OLS model. The LM test involves the following steps:

1. Estimate the regression equation by OLS and obtain the residuals.

2. Regress et on the original Xt and et-1, et-2,......i.e. lagged values of estimated residuals in step1.

3. If the sample size is large, Breusch and Godfrey have shown that:

$$
(\mathrm{n}-\mathrm{p}) \mathrm{R}^{2} \sim \chi^{2} \mathrm{p}
$$

Where, (n-p) times the R2 follows the chi square distribution with $p$ df. If in an application, (n-p) R2 exceeds the critical chi- square value at the chosen level of significance, we reject the null hypothesis of no serial correlation in the residuals (Gujarati 2016).

Both the tests are used in the study to detect the presence of serial correlation.

Further, for semi strong from, Event study methodology (Elton and Gruber, 2002) using daily returns and market model (Warner and Brown, 2012) is used. The demonetisation announcement was made on 8th November (5: 15 p.m.) after closing of stock market. Therefore, the announcement day for the study is considered as 9th November, 2016 and defined as " $t$ " $=0$. An event window of 31 days $(t=-$ 15 to $t=+15)$ is considered for the research. The daily returns of the firms $\left(R_{i t}\right)$ and the market index $\left(R_{m}\right)$ is calculated using formulae: Current daily return = (Current day price - Previous day price) / Previous day price. The Expected return (normal return) is calculated using the market model. For any security $i$, the market model is:

$$
E\left(R_{i t}\right)=\alpha_{i}+\beta_{i} R_{m t}+\dot{\varepsilon}_{i t}
$$

where, $E\left(R_{i t}\right)$ is the expected return on security $i$ on day $\mathrm{t}$; Rmt is the return on the market index on day $t$; and غंit is the zero mean disturbance term. ai, $\beta \mathrm{i}$ and cit are the parameters of the market model. To determine the parameters of the market model, Ordinary Least square method has been applied on the estimation window of 195 days prior to the event window. The NIFTY 50 is used as a proxy for the market index. Some of the earlier studies related to semi strong form of efficiency also adopted similar method where the firms constituting the index and market index are same (Ramachandran, 2013; Gupta, 2015). The Abnormal return (AR) for the firm $i$ in the event window is calculated as:

$$
A R_{i}=R_{i t}-E\left(R_{i t}\right)
$$

where, $R_{i t}$ is the actual return for the security $i$ during time $t$ and $E\left(R_{i t}\right)$ is the Expected return calculated using market model. The abnormal returns of individual securities are averaged for each day before and after the event day in the event window and the Average Abnormal Return (AAR) is obtained using formulae:

$$
\mathrm{AAR}_{t}=\Sigma{ }_{\mathrm{i}=1}^{\mathrm{N}}(\mathrm{AR})_{\mathrm{it}} / \mathrm{N} \text {, where } \mathrm{t}=-15 \text { to }+15 \text {. }
$$

Where, $(\mathrm{AR})_{\mathrm{it}}$ represents abnormal returns of the ith firm on the event day $t$ and $N$ refers to total number of firms.

Further, $\mathrm{Z}$ test has been used to test the significance 
of the abnormal returns around the demonetisation announcement date. $\mathrm{t}$ - test has been used to test the significant difference in the average abnormal returns before and after the demonetisation announcement date.

\section{FINDINGS OF THE STUDY}

Testing Weak form of Efficient Market Hypothesis
To test the weak form of EMH, firstly the actual returns on the daily closing share prices of the sample companies have been calculated. To test the movements of the calculated returns, serial correlation test has been used as described in the research methodology. The results are given in the following table 1 .

Table 1: Company wise result on Serial Correlation Test

\begin{tabular}{|c|c|c|c|c|}
\hline $\begin{array}{l}\text { Sr } \\
\text { No. }\end{array}$ & $\begin{array}{l}\text { Name of the Company } \\
\left(1^{\text {st }} \text { January - December } 16\right)\end{array}$ & $\begin{array}{l}\text { Durbin } \\
\text { Watson }\end{array}$ & $\begin{array}{l}\text { LM test prob } \\
\text { (chisquare) }\end{array}$ & Weak Form \\
\hline 1 & ACC Ltd. & 2.024 & 0.97 & Supported \\
\hline 2 & Adani Ports and Special Economic Zone Ltd. & 2.08 & 0.81 & Supported \\
\hline 3 & Ambuja Cements Ltd. & 2.066 & 0.39 & Supported \\
\hline 4 & Bharti Airtel Ltd. & 2.259 & 0.11 & Supported \\
\hline 5 & Asian Paints & 2.091 & 0.65 & Supported \\
\hline 6 & Aurobindo Pharma Ltd. & 2.175 & 0.032 & Rejected \\
\hline 7 & Axis Bank Ltd. & 1.9 & 0.55 & Supported \\
\hline 8 & Bajaj Auto Ltd & 2.05 & 0.87 & Supported \\
\hline 9 & Bharat Heavy Electricals Ltd & 1.97 & 0.91 & Supported \\
\hline 10 & Bank of Baroda & 2.27 & 0.001 & Rejected \\
\hline 11 & Bosch Ltd. & 1.97 & 0.52 & Supported \\
\hline 12 & Bharat Petroleum Corporation Ltd. & 2.03 & 0.91 & Supported \\
\hline 13 & Cipla Ltd. & 2.229 & 0.21 & Supported \\
\hline 14 & Coal India Ltd. & 2.089 & 0.134 & Supported \\
\hline 15 & Dr. Reddy's Laboratories Ltd. & 1.818 & 0.15 & Supported \\
\hline 16 & Eicher Motors Ltd. & 1.867 & 0.71 & Supported \\
\hline 17 & GAIL (India) Ltd. & 2.162 & 0.232 & Supported \\
\hline 18 & Grasim Industries Ltd. & 2.044 & 0.941 & Supported \\
\hline 19 & HCL Technologies Ltd. & 1.734 & 0.148 & Supported \\
\hline 20 & HDFC Bank Ltd. & 2.136 & 0.35 & Supported \\
\hline 21 & Housing Development Finance Corporation Ltd. & 2.094 & 0.23 & Supported \\
\hline 22 & Hero MotoCorp Ltd. & 2.022 & 0.97 & Supported \\
\hline 23 & Hindalco Industries Ltd. & 2.219 & 0.147 & Supported \\
\hline
\end{tabular}




\begin{tabular}{|c|c|c|c|c|}
\hline 24 & Hindustan Unilever Ltd. & 2.257 & 0.11 & Supported \\
\hline 25 & ICICI Bank Ltd. & 1.853 & 0.505 & Supported \\
\hline 26 & Idea Cellular Ltd. & 2.022 & 0.169 & Supported \\
\hline 27 & Indusland Bank Ltd. & 2.239 & 0.158 & Supported \\
\hline 28 & Infosys Ltd. & 1.907 & 0.043 & Rejected \\
\hline 29 & Bharti Infratel Ltd. & 1.95 & 0.038 & Rejected \\
\hline 30 & I T C Ltd. & 1.846 & 0.521 & Supported \\
\hline 31 & Kotak Mahindra Bank Ltd. & 2.274 & 0.1 & Supported \\
\hline 32 & Larsen \& Toubro Ltd. & 2.331 & 0.04 & Rejected \\
\hline 33 & Lupin Ltd. & 2.129 & 0.413 & Supported \\
\hline 34 & Mahindra \& Mahindra Ltd. & 2.078 & 0.731 & Supported \\
\hline 35 & Maruti Suzuki India Ltd. & 1.953 & 0.946 & Supported \\
\hline 36 & NTPC Ltd. & 2.081 & 0.817 & Supported \\
\hline 37 & Oil \& Natural Gas Corporation Ltd. & 1.92 & 0.591 & Supported \\
\hline 38 & Power Grid Corporation of India Ltd. & 2.178 & 0.038 & Rejected \\
\hline 39 & Reliance Industries Ltd. & 2.089 & 0.665 & Supported \\
\hline 40 & State Bank of India & 2.038 & 0.707 & Supported \\
\hline 41 & Sun Pharmaceutical Industries Ltd. & 2.011 & 0.774 & Supported \\
\hline 42 & Tata Consultancy Services Ltd. & 2.03 & 0.0009 & Rejected \\
\hline 43 & Tata Motors Ltd DVR & 2.019 & 0.06 & Supported \\
\hline 44 & Tata Motors Ltd. & 2.189 & 0.3332 & Supported \\
\hline 45 & Tata Power Co. Ltd. & 1.966 & 0.648 & Supported \\
\hline 46 & Tata Steel Ltd. & 1.857 & 0.561 & Supported \\
\hline 47 & Tech Mahindra Ltd. & 1.99 & 0.11 & Supported \\
\hline 48 & UltraTech Cement Ltd. & 2.054 & 0.084 & Supported \\
\hline 49 & Wipro Ltd. & 2.216 & 0.163 & Supported \\
\hline 50 & Yes Bank Ltd. & 1.98 & 0.99 & Supported \\
\hline 51 & Zee Entertainment Enterprises Ltd. & 2.36 & 0.018 & Rejected \\
\hline
\end{tabular}

*Significance at 5\% level. 
From the above table, it is analysed that Durbin Watson test supports the Weak Form of EMH for all the sample firms as no value is less than 1 and more than 3. But due to the presence of zone of indecision, Breusch Godfrey test has also been used. Further, since it is a time series data, Durbin Watson test may not be able to detect the higher order correlation therefore; Breusch Godfrey (LM) test has been used for the detection of the serial correlation in the residuals. According to LM test, 8 companies out of 51 companies rejected the weak form of EMH due to presence of serial correlation in the residuals. However, rest 43 companies supported the weak form of EMH. Thus the study supports the weak form of EMH.

\section{Testing Semi strong form of EMH}

To test the semi strong form of EMH, firstly expected returns are to be calculated. For this, regression coefficients using actual returns for each company and NIFTY 50 index are calculated. These are used as the parameters in the Ordinary Least Square Market Model to compute the expected returns. The following table 2 shows the computed regression coefficients. The abnormal returns of the individual companies are then calculated and averaged to provide Average Abnormal Return (AAR).

Table 2: Regression Coefficients of the sample companies.

\begin{tabular}{|l|l|l|}
\hline Company & Intercept & Beta \\
\hline ACC Ltd. & .001 & .905 \\
\hline Adani Ports and Special Economic Zone Ltd. & 0.000 & 1.486 \\
\hline Ambuja Cements Ltd. & 0.001 & .942 \\
\hline Asian Paints & 0.000 & 0.773 \\
\hline Aurobindo Pharma Ltd. & -0.001 & 1.225 \\
\hline Axis Bank Ltd. & 0.000 & 1.332 \\
\hline Bajaj Auto Ltd. & 0.000 & 0.886 \\
\hline Bank of Baroda & -.001 & 1.745 \\
\hline Bharat Heavy Electricals Ltd. & -.002 & 1.579 \\
\hline Bharat Petroleum Corporation Ltd. & -0.001 & 0.728 \\
\hline Bharti Airtel Ltd. & -.001 & 0.694 \\
\hline Bharti Infratel Ltd. & -0.001 & 0.593 \\
\hline Bosch Ltd. & 0.001 & 0.854 \\
\hline Cipla Ltd. & -0.001 & 0.564 \\
\hline Coal India Ltd. & -0.001 & 0.688 \\
\hline Dr. Reddy's Laboratories Ltd. & 0.000 & 0.719 \\
\hline Eicher Motors Ltd. & 0.000 & 0.980 \\
\hline GAIL (India) Ltd. & 0.000 & 0.980 \\
\hline Grasim Industries Ltd. & -0.003 & 0.978 \\
\hline HCL Technologies Ltd. & 0.000 & 0.637 \\
\hline
\end{tabular}




\begin{tabular}{|c|c|c|}
\hline HDFC Bank Ltd. & 0.000 & 0.763 \\
\hline Hero MotoCorp Ltd. & 0.001 & 1.009 \\
\hline Hindalco Industries Ltd. & 0.002 & 1.935 \\
\hline Hindustan Unilever Ltd. & 0.000 & 0.626 \\
\hline Housing Development Finance Corporation Ltd. & 0.000 & 1.031 \\
\hline I T C Ltd. & -.001 & 0.868 \\
\hline ICICI Bank Ltd. & 0.000 & 1.694 \\
\hline Idea Cellular Ltd. & -0.004 & 0.794 \\
\hline Indusland Bank Ltd. & 0.001 & 0.957 \\
\hline Infosys Ltd. & -0.001 & 0.769 \\
\hline Kotak Mahindra Bank Ltd. & 0.000 & 0.914 \\
\hline Larsen \& Toubro Ltd. & 0.000 & 1.486 \\
\hline Lupin Ltd. & -0.001 & 0.727 \\
\hline Mahindra \& Mahindra Ltd. & 0.000 & 0.953 \\
\hline Maruti Suzuki India Ltd. & 0.001 & 1.162 \\
\hline NTPC Ltd. & 0.000 & 0.862 \\
\hline Oil \& Natural Gas Corporation Ltd. & 0.000 & 0.969 \\
\hline Power Grid Corporation of India Ltd. & 0.001 & 0.714 \\
\hline Reliance Industries Ltd. & 0.000 & 0.876 \\
\hline State Bank of India & 0.000 & 1.728 \\
\hline Sun Pharmaceutical Industries Ltd. & -0.001 & 0.779 \\
\hline Tata Consultancy Services Ltd. & 0.000 & 0.730 \\
\hline Tata Motors Ltd DVR & 0.001 & 1.529 \\
\hline Tata Motors Ltd. & 0.001 & 1.851 \\
\hline Tata Power Co. Ltd. & 0.000 & 1.028 \\
\hline Tata Steel Ltd. & 0.002 & 1.552 \\
\hline Tech Mahindra Ltd. & -0.001 & 0.987 \\
\hline UltraTech Cement Ltd. & 0.001 & 0.982 \\
\hline Wipro Ltd. & -0.001 & 0.591 \\
\hline Yes Bank Ltd. & 0.002 & 1.332 \\
\hline Zee Entertainment Enterprises Ltd. & 0.001 & 1.028 \\
\hline
\end{tabular}

The analysis of semi strong form has been divided into two sections. First section analyses that whether demonetisation information yields any abnormal return on any of the days surrounding the announcement of information. Second section analyses the significant differences if any between the average abnormal returns before and after the announcement using paired t-test. 


\section{(1) AAR on each day surrounding the Announcement date.}

The AAR and CAAR of the companies were found out for the event window. With regards to this the hypothesis formulated is H02a -The AARs of the sample firms is zero in the event window (Das et.al. 2014). The test of significance of AAR has been done in the following manner:
If $\mathrm{Z}$ is the test statistic for $\mathrm{AAR}$, then $\mathrm{ZAAR}$ is defined as follows:

$$
\mathrm{Z}_{\mathrm{AAR}}=\mathrm{AAR}_{\mathrm{t}} / \sigma\left(\mathrm{AAR}_{\mathrm{t}}\right)
$$

The $\mathrm{Z}$ values in the following table 3 represent the values of test statistic for AAR. The test has been carried out at 1 per cent level of significance.

Table 3: $\mathrm{Z}$ test for each day

\begin{tabular}{|c|c|c|c|}
\hline Day & AAR & Z value & $\begin{array}{l}\text { Significance } \\
\text { level }\end{array}$ \\
\hline-15 & 0.004457 & 1.38971 & 0.165 \\
\hline-14 & 0.001220 & .23217 & 0.816 \\
\hline-13 & 0.000552 & -.00670 & 0.995 \\
\hline-12 & -0.000834 & -.50233 & 0.615 \\
\hline-11 & 0.001999 & .51074 & 0.610 \\
\hline-10 & 0.001120 & .19641 & 0.844 \\
\hline-9 & -0.006274 & -2.44766 & 0.014 \\
\hline-8 & 0.001689 & .39989 & 0.689 \\
\hline-7 & 0.001208 & .22788 & 0.820 \\
\hline-6 & 0.002173 & .57296 & 0.567 \\
\hline-5 & -0.000630 & -.42938 & 0.668 \\
\hline-4 & -0.000696 & -.45298 & 0.651 \\
\hline-3 & -0.003922 & -1.60659 & 0.108 \\
\hline-2 & 0.002608 & .72852 & 0.466 \\
\hline-1 & -0.000584 & -.41293 & 0.680 \\
\hline 0 & 0.001194 & .22288 & 0.824 \\
\hline 1 & 0.006125 & 1.98618 & 0.0470 \\
\hline 2 & -0.002505 & -1.09988 & 0.272 \\
\hline 3 & -0.000413 & -.35178 & 0.725 \\
\hline 4 & -0.000759 & -.47551 & 0.634 \\
\hline 5 & -0.000021 & -.21160 & 0.832 \\
\hline 6 & 0.003580 & 1.07610 & 0.282 \\
\hline 7 & -0.003737 & -1.54043 & 0.124 \\
\hline
\end{tabular}




\begin{tabular}{|l|l|l|l|}
\hline 8 & 0.001890 & .47176 & 0.637 \\
\hline 9 & 0.003460 & 1.03319 & 0.301 \\
\hline 10 & 0.002171 & .57225 & 0.567 \\
\hline 11 & -0.003220 & -1.35556 & 0.175 \\
\hline 12 & 0.004977 & 1.57566 & 0.115 \\
\hline 13 & 0.003615 & 1.08862 & 0.276 \\
\hline 14 & -0.001765 & -.83525 & 0.404 \\
\hline 15 & -0.000985 & -.55633 & 0.578 \\
\hline
\end{tabular}

${ }^{*}$ significant at $1 \%$ level;

The value of $Z$ lies between -2.58 and +2.58 for all the days in the event window. This means that the AARs in the event window are not significant. This implies that these AARs are not significantly different from zero. Therefore, the hypothesis (H02a) that abnormal returns earned surrounding the announcement date in the event window is zero is not rejected.

\section{(2) Average Abnormal Returns Before and After the Demonetisation Announcement}

The AARs of the company before and after the event are given below in the following table 4. With regards to this the hypothesis formulated is: $\mathrm{H} 02 \mathrm{~b}$ : There is no significant difference in the AARs before and after the announcement of demonetisation (Das et.al. 2014).

Table 4: AAR Before and After the Demonetisation Announcement

\begin{tabular}{|l|l|l|}
\hline $\begin{array}{l}\text { Event } \\
\text { Window }\end{array}$ & Average Abnormal Return (Before) & Average Abnormal Return (After) \\
\hline 1 & -0.00058 & 0.00613 \\
\hline 2 & 0.00261 & -0.00250 \\
\hline 3 & -0.00392 & -0.00041 \\
\hline 4 & -0.00070 & -0.00076 \\
\hline 5 & -0.00063 & -0.00002 \\
\hline 6 & 0.00217 & 0.00358 \\
\hline 7 & 0.00121 & -0.00374 \\
\hline 8 & 0.00169 & 0.00189 \\
\hline 9 & -0.00627 & 0.00346 \\
\hline
\end{tabular}




\begin{tabular}{|l|l|l|}
\hline 10 & 0.00112 & 0.00217 \\
\hline 11 & 0.00200 & -0.00322 \\
\hline 12 & -0.00083 & 0.00498 \\
\hline 13 & 0.00055 & 0.00362 \\
\hline 14 & 0.00122 & -0.00176 \\
\hline 15 & 0.00446 & -0.00099 \\
\hline
\end{tabular}

To test the statistical difference between AAR before and after the announcement, Paired $\mathrm{t}$ - test is applied and the result is shown in the following table 5.

Table 5: t-value for AAR before and after the Demonetisation Announcement

\begin{tabular}{|ll|l|l|l|l|l|}
\hline & \multicolumn{2}{|l|}{ Paired Differences } & T & df & Sig. (2-tailed) \\
\cline { 3 - 5 } & Mean & Std. Deviation & & \\
\hline Pair 1 $\begin{array}{l}\text { Before } \\
\text { After }\end{array}$ & -.000554758 & .004709507 & -.456 & 14 & .655 \\
\hline
\end{tabular}

The test result indicates that the difference between AAR before and after the demonetisation announcement is not significant at 5 percent level of significance. Therefore, the hypothesis $(\mathrm{H} 02 \mathrm{~b})$ that there is no significant difference in the average abnormal returns before and after the announcement is not rejected.

\section{CONCLUSION}

The Serial Correlation test used in the study indicates that the residuals of the stock are not correlated. Thus it can be concluded that the market is efficient in weak form of Efficient Market Hypothesis. The $\mathrm{Z}$ test indicates that the average abnormal returns earned around the demonetisation announcement are not significantly different from zero. Further, paired $t$ test used in the study also indicates that there is no difference in the abnormal returns earned before and after the demonetisation announcement. Therefore, it can be safely concluded that the market is efficient in semi strong form. An investor cannot earn abnormal returns using historical and current publicly available information.

Implication: Informational efficiency is one of the major criteria for assessing the strength of the stock market. A number of studies related to informational efficiency have been done, the debate still continues. Enhancing the efficiency of the market could create confidence in the market for Foreign Institutional Investors. This would facilitate more capital flows and will lead to further development of the Nation

\section{REFERENCES}

1) Abedini, B. (2009). An Evaluation of Efficiency of Tehran Stock Exchange. Doctoral Dissertation, The University of Mysore, Mysore.

2) Ahmad, K. M., Ashraf, S., \& Ahmed, S. (2006). 
Testing Weak Form Efficiency for Indian Stock Markets. Economic and Political Weekly, Vol. 41, N0. 1, pp. 49-56.

3) Ahmed, M. F. (2002). Market Efficiency in Emerging Stock Markets : The Case of Dhaka Stock Exchange (DSE). Savings and Development, Vol. 26, No. 1, pp. 49-68.

4) Ali, S. S., Mustafa, K., \& Zaman, A. (2002). Testing Semi Strong Form Efficiency of Stock Market. The Pakistan Development Review, Vol. 40, No. 4, pp. 651-674.

5) Arora, S., Makwana, K., \& Pathak, A. (2016). Event Study on Stock Prices of Maruti Suzuki India Limited- A Case Study on Launch of Celerio. Pacific Business Review International, Vol. 9 (Iss. 4 ), pp. 40 - 46.

6) Asiri, B. (2008). Testing Weak form Efficiency in the Bahrain Stock Market. International Journal of Emerging Markets, Vol. 3 (Iss. 1), pp. 38-53.

7) Balasubramanian, P. (1996). The Stock Market in India : A Test of Informationally Efficient Market Hypothesis. Doctoral Dissertation, Jawaharlal Nehru University, New Delhi.

8) Bapusaheb, S. U. (2012). A Study of Weak Form of Market Efficiency in India. Doctoral Dissertation, Aligarh Muslim University, Aligarh.

9) Bharath, M. (2013). Market Efficiency of Indian Stock Market- A Study with Reference to Bombay Stock Exchange, Annamalai University, Chidambaram.

10) Bhuniya, R. (2004). Behaviour of Share Prices in India During Post Reform Period : A Test of Weak Form of Market Efficiency. Doctoral Dissertation, University of Burdwan, West Bengal.

11) Biktimirov, E. N., \& Durrani, F. (2017). Market reactions to corporarte name changes : evidences from Toronto Stock Exchange. International Journal of Managerial Finance, Vol. 13 (Iss 1), pp. 50-69.

12) Burton, B. (2005). Concurrent capital expenditure and stock market reaction to corporate alliance announcements. Applied Financial Economics, Vol. 15 : 10, pp. 715-729.
13) Campbell, K., \& Ohuocha, C. (2011). The stock market reaction to stock dividends in Nigeria and their information content. Managerial Finance, Vol. 37 (Iss. 3), pp. 295-391.

14) Chahal, S. S. (1998). An Empirical Study of The Efficiency of Indian Capital Market. Doctoral Dissertation, Maharshi Dayanand University, Rohtak.

15) Clarke, J., Jandik, T., \& Mandelker, G. (2001). The Efficient Markets Hypothesis. Investment Strategies from Industry Leaders, pp. 126-141.

16) Cooper, D. R., \& Schindler, P. S. (2006). Business Research Methods. Tata Mc Graw Hill.

17) Cooray, A., \& Wickremasinghe, G. (2007). The Efficiency of Emerging Stock Markets: Empirical Evidence from South Asian Region. The Journal of Developing Areas, Vol. 41, No. 1, pp. 171183.

18) Das, S., Pattanayak, J. K., \& Pathak, P. (2014). Effect of quarterly earnings announcement under different market conditions An empirical study of companies constituting SENSEX. Journal of Indian Business Research, Vol. 6 (Iss2), pp. - 128-154.

19) Elton, E. J., \& Gruber, M. J. (2002). Modern Portfolio Theory and Investment Analysis. Wiley.

20) Deena, R. (2013). Stock Market and Economic Development. Doctoral Dissertation, Kerala University, Thiruvanthapuram.

21) Dsouza, J. J., \& Mallikarjunappa, T. (2016). Quarterly Earnings and Stock Prices Reactions A Study of BSE 500 Companies. Amity Journal of Finance, Vol. 1. No. 1, pp. 9- 35.

22) Fama, E. F., Fisher, L., Jensen, M. C., \& Roll, R. (1969). The Adjustment of Stock Prices to New Information. International Economic Review, Vol. 10 : 1, pp. 1-21.

23) Gujarati, D. N., Porter, D. C., \& Gunasekar, S. (2016). Basic Econometrics. Mc Graw Hill.

24) Gupta, H. (2015). A Study on Impact of Union Budget on Stock Market (NIFTY). Journal of Advanced Research in Accounting and Finance Management, Vol. 1 (Iss. 2), pp. 1-6.

25) Howe, J. S. (1986). Evidence on Stock Market 
Overreaction. Financial Analysts Journal, Vol. 42, No. 4, pp. 74-77.

26) Huang, X. (2004). China Stock Price Reactions to Financial Announcements: Evidence from Segmented Markets. Managerial Finance, Vol. 30, pp. 62-73.

27) Jain, P., Vyas, V., \& Roy, A. (2013). A study on weak form of market efficiency during the period of global financial crisis in the form of random walk on Indian capital market. Journal of Advances in Management Research, Vol. 10 (Iss. 1), pp. 122- 138.

28) Jiang, L. (2011). Order Imbalance, Liquidity and Market Efficiency : Evidnece from Chineese Stock Market . Managerial and Decision Economics, Vol. 32, No. 7, pp. 469- 490.

29) Kumar, S. (2014). Testing of Efficient Market Hypothesis in its Semi Strong Form in Indian Context. Doctoral Dissertation, Anna University, Chennai.

30) Kumar, S., Mahadevan, A., \& Gunasekar, S. (2012). Market Reaction to Dividend Announcement: An Empirical Study Using Event Study Technique. Prestige International Journal of Management \& IT- Sanchayan , Vol. 1 :1, pp. 141-153.

31) Kummeta, R.S. (2015). Event Study Analysis of Semi-Strong Form of Capital Market Efficiency (With Special Reference to Internal Event Announcements of Listed Companies in BSE and NSE. Doctoral Dissertation, Sri Krishnadevaraya University, Andhra Pradesh.

32) Lahiri, M. (2012). Predictability Of Share Prices In India During Post-Reform Period: A Test Of Semi-Strong Form Of Market Efficiency. Doctoral Dissertation. The University of Burdwan, West Bengal.

33) Manickaraj, M. (2004). Information Content of Quarterly Earnings and Efficiency of Indian Capital Markets : An Empirical Study, Doctoral Dissertation, Periyar E.V.R. College, Tiruchirapalli.

34) Nadig, A. (2014). An Empirical Study on SemiStrong Form of Market Efficiency of Select Sectors in Bombay Stock Exchange, Doctoral
Dissertation, Manipal University, Banglore.

35) Niarchos, N. A., \& Georgakopoulos, M. C. (1986). The Effect of Annual Corporate Profit Reports on the Athens Stock Exchange : An Empirical Investigation. Mangement International Review , Vol. $26: 1$, pp. 64-72.

36) Olowe, A. R. (1998). Stock Splits and The Efficiency of The Nigerian Stock Market. African Review of Money Finance and Banking , No. 1/ 2, pp. 97- 126.

37) Patten, D. M. (2008). Does the Market Value Corporate Philanthropy? Evidence from the Response to the 2004 Tsunami Relief Effort. Journal of Business Ethics, Vol. 81 : 3, pp. 599607.

38) Raja,. M. (2008). Testing the efficiency of Indian Stock Market with respect to Information Content of Corporate Event Announcements - A Study on Information Technology Companies, Doctoral Dissertation, Bharathidasan University, Tiruchirapalli.

39) Rahmanizadeh, F. (2015). Stock Market Efficiency: An Empirical Study of Select Sectors in NSE, Doctoral Dissertation, University of Mysore, Mysore.

40) Ramachandran, R. (2012). Effect of Corporate Information Release and its Context on Price and Volume of Shares. Doctoral Dissertation, C.M.S. College, Kottayam.

41) Reilly, F. K., \& Brown, K. C. (2012). Analysis of Investments and Management of Portfolios. Cengage Learning.

42) Robinson, J. (2005). Stock Price Behaviour in Emerging Markets : Tests for Weak Form Market Efficiency on The Jamaica Stock Exchange. Social and Economic Studies, Vol. 54, No. 2, pp. 51-69.

43) Sharma, G., \& Mahendru, M. (2009). Efficient Hypothesis of the Stock Markets : A Case of Indian Securities. International Journal of Business and Management, Vol. 4, No. 3, pp. 136- 144.

44) Siddiqui, S., \& Gupta, P. K. (2010). Weak Form of Market Efficiency- Evidences from selected NSE indices. SSRN Electronic Journal .Singh, D. (1998). An Empirical Study of the Efficiency of 
Indian Capital Market. Doctoral Dissertation, Maharshi Dayanand Uiversity, Rohtak.

45) Thomas, S., \& Shah, A. (2002). Stock Market Response to Union Budget. Economic and Political Weekly , Vol. 37, No. 5, pp. 455- 458.
46) Woolridge, J. R., \& Snow, C. C. (1990). Stock Market Reaction to Strategic Invetment Decisions. Strategic Management Journal, Vol. 11, pp. 353-363. 